\title{
"PENINGKATAN HASIL BELAJAR MATA PELAJARAN FIQIH MELALUI PENERAPAN METODE PQRST (PREVIEW, QUESTION, READ, SUMMARIZE, TEST) PESERTA DIDIK KELAS V DI MI ISMARIA AL-QUR'ANIYAH ISLAMIYAH RAJA BASA BANDAR LAMPUNG TAHUN PELAJARAN 2016/2017".
}

\author{
Uswatun Hasanah \\ uswatunhasanah@radenintan.ac.id \\ Universitas Islam Negeri Raden Intan Lampung
}

\begin{abstract}
The purpose of the study was to determine whether the application of the PQRST method can improve the learning outcomes of students in Class V MI. This research is Classroom Action Research (CAR) because in class action research can study learning problems in the classroom through reflection to solve problems by doing planned actions in real situations and analyzing each influence of the treatment. Data collection methods used are the method of observation, interviews, documentation, and tests. The sample in this study is class $V$ students of Ismaria Al-Qur'aniyyah Islamiyah Raja Basa Bandar Lampung 2016/2017. This research was conducted in two cycles. Cycle I with the material Knowing Halal Food and Drinks, cycle II consists of Knowing Food and Beverages. Based on the results of the study, it was concluded that through the application of the PQRST method (Preview, Question, Read, Summarize and Test) can improve the learning outcomes of fiqh subjects in fifth grade students in MI 2016/2017 academic year.
\end{abstract}

Keywords: Fiqh; PQRST method; and Improving Learning Outcomes.

\begin{abstract}
Abstrak
Tujuan dari penelitian adalah untuk mengetahui apakah penerapan metode PQRST dapat meningkatkan hasil belajar siswa Kelas V MI. Penelitian ini adalah penelitian Tindakan Kelas (PTK) karena pada penelitian tindakan kelas dapat mengkaji permasalahan pembelajaran di dalam kelas melalui refleksi untuk memecahkan masalah dengan cara melakukan tindakan yang terencana dalam situasi nyata serta menganalisis setiap pengaruh dari perlakuan tersebut. Metode pengumpulan data yang digunakan yaitu metode observasi, wawancara, dokumentasi, dan tes. Adapun sampel pada penelitian ini adalah Peserta didik kelas V MI Ismaria Al-Qur'aniyyah Islamiyah Raja Basa Bandar Lampung 2016/2017. Penelitian ini dilaksanakan dalam dua siklus. Siklus I dengan materi Mengenal Makanan dan minuman Halal, siklus II terdiri dengan materi Mengenal Makanan dan Minuman HaramBerdasarkan hasilpenelitian, maka disimpulkan bahwamelaluipenerapanmetode PQRST (Preview, Question, Read, Summarize and Test) dapatmeningkatkanhasilbelajar matapelajaranfiqhPesertadidikkelas V di MI tersebut tahun pelajaran 2016/2017.
\end{abstract}

Kata Kunci : Fiqih;Metode PQRST; dan Peningkatan Hasil Belajar. 


\section{PENDAHULUAN}

Pendidikan Agama Islam adalah agama penyeimbang antar dunia dan akhirat, Islam tidak mempertentangkan antara iman dengan ilmu, bahkan menurut Rasulullah SAW, Islam mewajibkan manusia, baik laki-laki maupun perempuan untuk belajar dan mendalami ilmu pengetahuan sejak dari buaian hingga akhir kehidupan : "Minal mahdi ilal lahd", yaitu dengan pendidikan seumur hidup. Tanpa ilmu, hidup dan kehidupan manusia pasti tidak akan bermutu, dengan agama dalam kegiatan pembelajaran akan menjadikan hidup ini terarah, dan lebih bermakna. Oleh karena itu, dengan ilmu yang baik dan agama Islam kehidupan manusia menjadi sempurna, bahagia dan penuh rahmat. Dalam kehidupan masyarakat modern agama pun tetap diperlukan oleh manusia(Sada, 2016).

Kegiatan belajar mengajar merupakan kegiatan yang paling pokok. Hal ini berhasil tidaknya pencapaian tujuan pendidikan banyak bergantung dari bagaimana proses belajar yang dialami oleh peserta didik (Selameto, 1995). Peserta didik merupakan kunci terjadinya perilaku belajar dan tercapainya sasaran belajar, karenanya guru harus dapat memilih cara mengajar yang baik dan menggunakan strategi, metode, model pembelajaran, serta pendekatan pembelajaran yang sesuai agar dapat meningkatkan hasil belajar Peserta didik.

Menurut (Selameto, 1995), Belajar ialah suatu proses usaha yang dilakukan seseorang untuk memperoleh suatu perubahan tingkah laku yang baru secara keseluruhan, sebagai hasil pengalamannya sendiri dalam interaksi dengan lingkungannya. Kemampuan-kemampuan yang di miliki peserta didik setelah ia mengalami pengalaman belajarnya atau perubahan tingkah laku yang terjadi sebagai akibat dari kegiatan belajar yang telah di lakukan individu atau peserta didik (Sudjana, 2004).

Hasil belajar mempunyai peranan penting dalam proses pembelajaran , untuk mewujudkan hasil belajar yang baik, dan menjadikan anak didik (peserta didik) semangat untuk belajar maka perlu adanya seorang pendidik (guru) yang professional diantaranya memiliki metode atau strategi tersendiri di dalam mengajar. Seorang guru dituntut untuk dapat mengembangkan program pembelajaran yang optimal, sehingga 
terwujud proses pembelajaran yang efektif dan efisien. Setidaknya, hasil belajar dapat dicapai dengan baik jika melalui Metode PQRST (Preview, Question. Read, Summarize, Test). Metode PQRST (Preview, Question. Read, Summarize, Test) merupakan suatu metode belajar yang meminta Peserta didik untuk melakukan Preview (membaca sekilas), Question (bertanya), Read (membaca), Summarize(meringkas), dan Test(menguji) (Nurhadi, 1987). Metode PQRST merupakan salah satu alternatif perbaikan proses pembelajaran yang cenderung membosankan dan sebagai pelengkap cara-cara tradisional untuk meningkatkan kwalitas pembelajaran membaca(Purwati, 2016). Beberapa penelitian terdahulu telah menggunakan metode ini dalam penelitiannya seperti yang dilakukan oleh (Purwati, 2016), (Wahid \& Amarwanti, 2015), (Hidayah, Suwandi, \& Hastuti, 2014), (Nur Canggih Tri Wiguna, 2015), (Mariana, Miharty, \& Thaib, 2015), (Milasari, Mahfud, Sadiman, \& Sriyanto, 2015), (Ardana, Suandi, \& Artawan, 2014), (Sukaesih, 2014), (Wahyuni, Putra, \& Abadi, 2014), dan (Jayanthi, Garminah, \& Md. Suarjana, 2013).

Segi proses pembelajaran dikatakan berhasil dan berkualitas apabila seluruh atau setidak-tidaknya sebagian besar (75\%) peserta didik secara aktif, baik fisik, mental maupun sosial dalam proses pembelajaran, di samping menunjukkan kegairahan belajar yang tinggi, semangat belajar yang besar dan rasa percaya pada diri sendiri. Sedangkan dari segi hasil, proses pembelajaran dikatakan berhasil apabila terjadi perubahan yang positif dari peserta didik seluruhnya atau setidak-tidaknya sebagian besar (75) (Mulyasa, 2004). Suatu proses belajar mengajar yang efektif dan bermakna akan berlangsung apabila dapat memberikan keberhasilan bagi Peserta didik ataupun guru itu sendiri (Depdikbud, 1996).

Berdasarkan pemikiran dan latar belakang yang telah peneliti kemukakan di atas ada sebuah fenomena yang menarik, bagaimana guru dituntut untuk dapat mengajarkan pelajaran Fiqih dengan alokasi waktu yang terbatas dengan latar belakang kemampuan peserta didik (input) yang berbeda. Guru harus menerapkan strategi atau metode belajar yang tepat bagi Peserta didik, agar materi yang disampaikan dapat diterima dan dipahami dengan baik dan benar dalam waktu yang telah ditentukan. Fenomena inilah yang membuat peneliti tertarik untuk mengadakan sebuah studi penelitian dan 
menjawab sebuah permasalahan yang berkaitan dengan hal tersebut sehingga peneliti mengangkat sebuah penelitian yang bertujuan untuk mengetahui penerapan metode PQRST dapat meningkatkan hasil belajar siswa KelasV MI.

\section{METODE PENELITIAN}

Penelitian ini adalah Penelitian Tindakan Kelas (PTK) karena pada penelitian tindakan kelas dapat mengkaji permasalahan pembelajaran di dalam kelas melalui refleksi untuk memecahkan masalah dengan cara melakukan tindakan yang terencana dalam situasi nyata serta menganalisis setiap pengaruh dari perlakuan tersebut. Istilah PTK dalam Bahasa Inggris adalah Classroom Action Research (CAR) yaitu sebuah kegiatan penelitian yang dilakukan di kelas (Arikunto, 2008).

Model penelitian tindakan kelas secara garis besar terdapat empat rangkaian tahapan yang lazim dilalui, yaitu (1) Perencanaan (Planning), (2) Pelaksanaan (Acting), (3) Pengamatan (Observing), (4) Refleksi (Reflecting), yang dilaksanakan dalam bentuk siklus berulang dan setiap siklus harus terdapat keempat tahapan tersebut.

Tindakan yang diterapkan dalam penelitian tindakan kelas seperti yang digambarkan dalam bagan diatas adalah terdiri dari 4 tahap. Secara rinci tahapan penelitian ini sebagai berikut:Pertama, Perencanaan, yaitu menyusun rancangan tindakan.(a) Mengidentifikasi masalah, (b) Mencarikan alternative pemecah, dan (c) Membuat satuan tindakan (pemberian bantuan).KeduaPelaksanaan tindakan, yaitu implementasi atau penerapan isi rancangan di dalam kancah, yaitu mengenakan tindakan di kelas; Kegiatan yang dilaksanakan dalam tahapan ini adalah melaksanakan tindakan upaya meningkatkan hasil belajar dalam pembelajaran bidang studiFiqhyang telah direncanakan. Ketiga, Observasi, yaitu pelaksanaan pengamatan oleh pengamat.Dalam tahap ini dilaksanakan observasi terhadap pelaksanaan tindakan dengan menggunakan observasi ylang telah dipersiapkan. Peneliti mempersiapkan lembar observasi yang telah disiapkan untuk mengetahui kondisi kelas terutama hasil belajar peserta didik dalam pembelajaran. Dalam penelitian ini hasil pengamatan kemudian didiskusikan dengan kolaburator yaitu Guru bidang studi Fiqih untuk dicari 
solusi dari permasalahan yang ada pada waktu pembelajaran berlangsung.Keempat, Refleksi, yaitu kegiatan untuk mengemukakan kembali apa yang sudah terjadi.

Adapun metode pengumpulan data yang akan penulis gunakan adalah sebagai berikut :

\section{a. Metode Observasi}

Metode observasi adalah suatu cara pengumpulan data yang dilakukan dengan sengaja melalui pengamatan dan pencatatan terhadap gejala-gejala, peristiwa peristiwa dari obyek yang selidiki(Arikunto, 2008). Adapun jenis observasi yang diterapkan dalam penelitian ini adalah observasi partisipan, dimana peneliti turut ambil bagian atau berada dalam keadaan obyek yang diobservasi (observer). Metode ini merupakan salah satu metode pokok yang digunakan penulis untuk mengetahui keadaan MI Ismaria Al-Qur'aniyyah Islamiyah pada pembelajaran Fiqih yang sebenarnya di lapangan.

\section{b. Metode Wawancara}

Metode wawancara atau interview adalah suatu cara pengumpulan data yang digunakan untuk memperoleh informasi langsung dari sumbernya (Riduwan, 2007). Teknik interview yang digunakan adalah interview bebas terpimpin yaitu tanya jawab secara bebas dengan berpedoman pada pokok-pokok yang ditentukan terlebih dahulu.Adapun interview ini ditujukan kepada Gurubidang study Fiqih dan Peserta didik kelas V di MI Ismaria Al-Qur'aniyah Islamiyah, yang dapat memberikan informasi tentang data yang dibutuhkan oleh peneliti tentang penerapan Metode PQRST (Preview, Question, Read, Summarize, Test) dalam pembelajaran Fiqih.

\section{c. Metode Dokumentasi}

Metode Dokumentasi adalah alat pengumpulan data yang digunakan untuk mencari, mengenal hal - hal atau variable yang berupa catatan, transkip buku, surat kabar, majalah, peraturan - peraturan, notulen rapat dan sebagainya(Arikunto, 2008). Metode ini penulis gunakan untuk memperoleh data tentang gambaran umum sekolah, seperti letak geografis, struktur organisasi dan hal - hal yang berkaitan dengan sekolah dan proses belajar mengajar sehingga diperoleh gambaran yang jelas tentang sekolah yang akan penulis teliti. Metode dokumentasi juga digunakan oleh 
peneliti untuk memperoleh gambaran ketika proses belajar mengajar dengan metode PQRST (Preview, Question, Read, Summarize, Test) yang dilaksanakan.

\section{d. Metode Test}

(Nurkencana, 1993) mengatakan bahwa tes adalah suatu cara untuk mengadakan penilaian yang berbentuk suatu tugas yang harus dikerjakan anak atau sekelompok anak sehingga menghasilkan suatu nilai tentang tingkah laku atau prestasi anak tersebut yang kemudian dapat dibandingkan dengan nilai yang dicapai oleh anakanak lain atau standar yang telah ditetapkan. Test sebagai instrumen sangat lazim digunakan dalam penelitian tindakan kelas. Hal ini disebabkan dalam penelitian tindakan kelas pada umumnya salah satu yang diukur adalah prestasi belajar yang dapat dilihat dari peningkatan hasil belajar peserta didik. Peneliti menggunakan metode test ini untuk mengumpulkan data-data mengenai hasil belajar peserta didik pada mata pelajaran Fiqih kelas V MI Ismaria Al-Qur'aniyah Islamiyah.

Analisis data adalah proses mencari dan menyusun sistematis data yang diperoleh dari hasil wawancara, catatan lapangan, data dokumentasi, dengan cara mengorganisasikan data ke dalam kategori, menjabarkan ke dalam unit-unit, melakukan sintesa, menyusun ke dalam pola, memilih mana yang penting dan yang akan dipelajari, dan membuat kesimpulan sehingga mudah difahami oleh diri sendiri maupun orang lain (Sugiyono, 2011).

Adapun penulis dalam menganalisis data ialah dengan menggunakan pendapat (Sugiyono, 2011), dengan menggunakan beberapa metode yaitu;

a. Data Reduction (Reduksi Data), pada tahap ini penulis mengumpulkan data yang diperoleh dari lapangan, kemudian merangkum, memilih hal-hal yang penting, mencari tema dan polanya dan membuang yang tidak perlu.

b. Data Display (Penyajian Data), langkah ini dilakukan setelah data direduksi dalam bentuk uraian singkat dan dalam bentuk teks naratif.

c. Calculation Drawing/verification, Penarikan Kesimpulan dan Verifikasi .

Berdasarkan penjelasan di atas penulis mengambil tahapan dalam menganalisis data dalam penelitian tindakan kelas ini, dengan penjelasan sebagai berikut: (a) Reduksi data proses menyeleksi, menentukan fokus meyederhanakan dan meringkas serta 
merubah data 'mentah' menjadi data lapangan. (b) Penyajian data adalah penjabaran data sedemikian rupa sehingga dapat dipahami secara jelas. (c) Penarikan kesimpulan merupakan upaya memberikan penilaian atau interpretasi berdasarkan penyajian data yang telah dilakukan.

Kesimpulan dalam penelitian kualitatif mungkin dapat menjawab rumusan masalah yang dirumuskan sejak awal, tetapi mungkin juga tidak, karena seperti telah dikemukakan bahwa masalah dan rumusan masalah dalam penelitian kualitatif masih bersifat sementara dan akan berkembang setelah penelitian lapangan.

Verifikasi data ini penulis mengkonfergensikan data reduksi dan display selanjutnya melakukan verifikasi data dengan mencocokkan teori yang terkait dengan Metode pembelajaran PQRST)dalam meningkatkan hasil belajar pada pelajaranFiqih Peserta didik kelas V MI Ismaria.

$$
P=\frac{\mathrm{F}}{\mathrm{N}}
$$

Untuk mengetahui rata-rata hasil belajar peserta didik digunakan rumus (Sudjiono, 2008):

\section{Keterangan:}

$\mathrm{P}=$ Persentase rata-rata nilai peserta didik

$\mathrm{F}=$ Frekuensi hasil peserta didik

$\mathrm{N}=$ Jumlah seluruh peserta didik.(Sudjiono, 2008)

\section{Skala Keberhasilan Penelitian}

Jika hasil P

$$
\begin{array}{lll}
80-100=\text { Sangat Baik } & 40-59=\text { Cukup } \\
60-79=\text { Baik } & 20-39=\text { Kurang } \\
& 0-19=\text { Sangat Buruk }
\end{array}
$$

Penelitian tindakan kelas ini akan berakhir jika ketuntasan seluruh peserta didik mencapai $75 \%$ atau lebih. 


\section{HASIL PENELITIAN DAN PEMBAHASAN}

Berikut ini penulisan mengungkapkan dan menganalisa data yang berkaitan dengan hasil penelitian sebagai berikut: Penerapan Metode PQRST (Preview, Question. Read, Summarize and Test) Dalam Meningkatkan Hasil Belajar Peserta didik.

Berdasarkan pra survey: sebelum penerapan metode PQRST (Preview, Question. Read, Summarize and Test) metode yang diterapkan oleh guru di MI tempat penelitian ini wabil khusus, metode yang dipakai dalam pembelajaran Fiqih adalah dengan menggunakan metode ceramah dan Tanya jawab. Sehingga berdampak terhadap nilai hasil belajar peserta didik pada mata pelajaran Fiqih masih banyak yang belum mencapai KKM. Dari 34 peserta didik yang telah mencapai ketuntasan adalah 10 Peserta didik $(29,41 \%)$ sedangkan yang belum mencapai ketuntasan adalah 24 Peserta didik (70,58\%), yang artinya hasil belajar mereka tergolong rendah.

Penelitian ini dilaksanakan dalam dua siklus. Siklus I dengan materi Mengenal Makanan dan minuman Halal, siklus II terdiri dengan materi Mengenal Makanan dan Minuman Haram. Hasil penelitian diuraikan dalam tahapan yang berupa siklus-siklus pembelajaran yang dilakukan dalam proses belajar mengajar di kelas. Dalam penelitian ini pembelajaran dilakukan dalam dua siklus sebagaimana pemaparan berikut ini:

\section{Perencanaan}

Dalam perencanaan pembelajaran siklus I ini, peneliti menerapkan Metode Pembelajaran PQRST dalam proses belajar mengajar dengan tujuan untuk meningkatkan hasil belajar pembelajaran Peserta didik terhadap pokok bahasan materi Makanan dan Minuman Halal. Adapun pada perencanaan ini peneliti mempersiapkan beberapa tahapan yaitu:

a. Membuat rencana pelaksanaan pembelajaran (RPP) dengan menggunakan Metode Pembelajaran PQRST (Preview, Question, Read, Summarize and Test).

b. Mempersiapkan materi ajar yaitu Makanan dan Minuman Halal

c. Membuat lembar kerja Peserta didik 
d. Mempersiapkan lembar observasi pembelajaran untuk mengukur peningkatan hasil belajar Peserta didik yang akan digunakan pada saat pembelajaran.

\section{Pelaksanaan}

Pada pertemuan ini pelaku tindakan mengajar adalah guru Mata Pelajaran Fiqih. Sedangkan peneliti mengadakan observasi proses pembelajaran yang dilakukan oleh Mata Pelajaran Fiqih dan proses pembelajaran yang dilakukan oleh Peserta didik. Untuk lebih jelasnya penerapan metode PQRST dalam penelitian ini bisa dipaparkan sebagai berikut:

\section{a. Kegiatan Awal:}

Pada awal pembelajaran peneliti langsung melakukan pengamatan dengan menggunakan lembar observasi guru mata pelajaran Fiqih memulai kegiatan pembelajaran dengan mengucapkan salam, setelah itu mengabsen peserta didik. Pembelajaran Fiqih pada pertemuan pertama dihadiri 34 peserta didik. Kemudian guru memperkenalkan peneliti kepada peserta didik dan memberitahukan tujuan peneliti berada di kelas V tersebut. Selanjutnya guru menjelaskan kepada peserta didik bahwa mulai hari ini pelaksanaan pembelajaran Fiqih akan sedikit berbeda dengan hari biasanya, yaitu pembelajaran hari ini dan pertemuan berikutnya akan diterapkan Metode PQRST (Preview, Question, Read, Summarize and Test). dimana pembelajaran lebih terpusat pada peserta didik, dengan cara yang lebih menyenangkan dan mengekspresikan kreativitas peserta didik. Pada waktu peneliti menjelaskan tentang Strategi pembelajaran yang akan digunakan, peserta didik sangat antusias, namun masih ada beberapa peserta didik yang tidak memperhatikan penjelasan peneliti. Selanjutnya peneliti secara berkolaborasi dengan pendidik memberikan apersepsi dan motivasi.

b. Kegiatan inti :

1) Langkah pertama ini dimaksudkan agar Peserta didik membaca dengan cepat sebelum mulai membaca bahan bacaan Peserta didik yang memuat tentang isi materi yang akan dipelajarinya. 
2) Langkah kedua ini adalah menyusun atau mengajukan pertanyaan kepada diri sendiri mengenai isi buku atau untuk setiap pasal yang ada pada bahan bacaan Peserta didik.

3) Langkah ketiga ini Peserta didik membaca secara teliti paragraph demi paragraph untuk lebih memahami isi bacaan atau materi yang ada dalam buku, sambil mencoba mencari jawaban untuk pertanyaan-pertanyaan yang telah disusun tadi.

4) Langkah empat ini Peserta didik berhenti sebentar untuk meringkas atau membuat catatan penting mengenai apa yang sudah dibacanya tadi.

\section{Observasi}

Pada pertemuan pertama di siklus I ini, Hasil belajar Peserta didik masih rendah atau belum sesuai dengan yang diharapkan oleh peneliti. Pada pertemuan pertama ini tidak semua Peserta didik aktif membuat pertanyaan yang tepat dengan materi yang ada. Adapun masalah yang dihadapi yaitu Peserta didik sibuk sendiri dan mengobrol dengan teman-temannya pada saat di minta membaca cepat dan menyusun pertanyaan, ada Peserta didik yang melamun, Peserta didik dalam bertanya dan menjawab tidak serius.

\section{Refleksi}

Berdasarkan data hasil tes pada siklus I diatas diketahui bahwa setelah menggunakan Metode PQRST dalam proses belajar mengajar pada materi makanan dan minuman yang halal dan haram mengalami peningkatan yang cukup baik. Dari hasil pengamatan selama proses belajar mengajar berlangsung Peserta didik yang belum mencapai KKM disebabkan beberapa faktor diantaranya masih terdapat Peserta didik yang tidak serius dalam mengerjakan tugas yang diberikan oleh pendidik, sikap saling mengandalkan satu sama lain, kurang berani dalam bertanya ketika kelompok lain sedang presentasi, sehingga hal ini membuat beberapa Peserta didik tidak sepenuhnya maksimal dalam mengerjakan soal tes yang diberikan oleh pendidik pada akhir pelajaran. Yang kemudian berpengaruh pada hasil belajar yang didapatnya belum mencapai target. 
Berdasarkan hasil penilaian dan pengamatan pendidik terhadap peneliti selama proses pembelajaran siklus I dan siklus II, hasil peneliti mengalami peningkatan. Pada siklus I kinerja peneliti belum optimal, masih terdapat banyak kekurangan-kekurangan. Namun pada pelaksanaan siklus II kinerja peneliti sudah baik dan optimal.

Pembelajaran dengan menggunakan Metode PQRST telah banyak memberikan kontribusi terhadap peningkatan hasil belajar Peserta didik di kelas dan menunjukkan jika setiap Peserta didik memiliki interaksi dalam pembelajaran Fiqih yang berbedabeda. Selain itu, pemberian reward/hadiah merupakan wujud penghargaan atas hasil kerja dalam pembelajaran. Sehingga hal ini berdampak pada hasil belajar yang meningkat. Untuk lebih jelasnya dapat dilihat pada Tabel berikut:

\section{Tabel 1}

\section{Data hasil belajar matapelajaranFiqh Peserta didik}

Peserta didik kelas V MI Ismaria Al-Qur'aniyyah Islamiyah

Raja Basa Bandar Lampung 2016/2017.

\begin{tabular}{|c|l|c|c|c|c|}
\hline No & NilaiHasilBelajar & Pra survey & Siklus I & Siklus II & $\begin{array}{c}\text { Keteranga } \\
\mathrm{n}\end{array}$ \\
\hline 1 & Tuntas & $\begin{array}{c}10 \\
(29,41 \%)\end{array}$ & $\begin{array}{c}19 \\
(55,88 \%)\end{array}$ & $\begin{array}{c}28 \\
(82,35 \%)\end{array}$ & \\
\hline 2 & BelumTuntas & $\begin{array}{c}24 \\
(70,59 \%)\end{array}$ & $\begin{array}{c}15 \\
(44,22 \%)\end{array}$ & $\begin{array}{c}06 \\
(17,65 \%)\end{array}$ & \\
\hline & & $34(100 \%)$ & 34 & 34 & \\
& & $(100 \%)$ & $(100 \%)$ & \\
\hline
\end{tabular}

Untuk lebih jelas nya dapat dilihat pada diagram berikut: 


\section{Gambar 1.}

\section{Diagram Presentase Hasil Belajar Peserta didik}
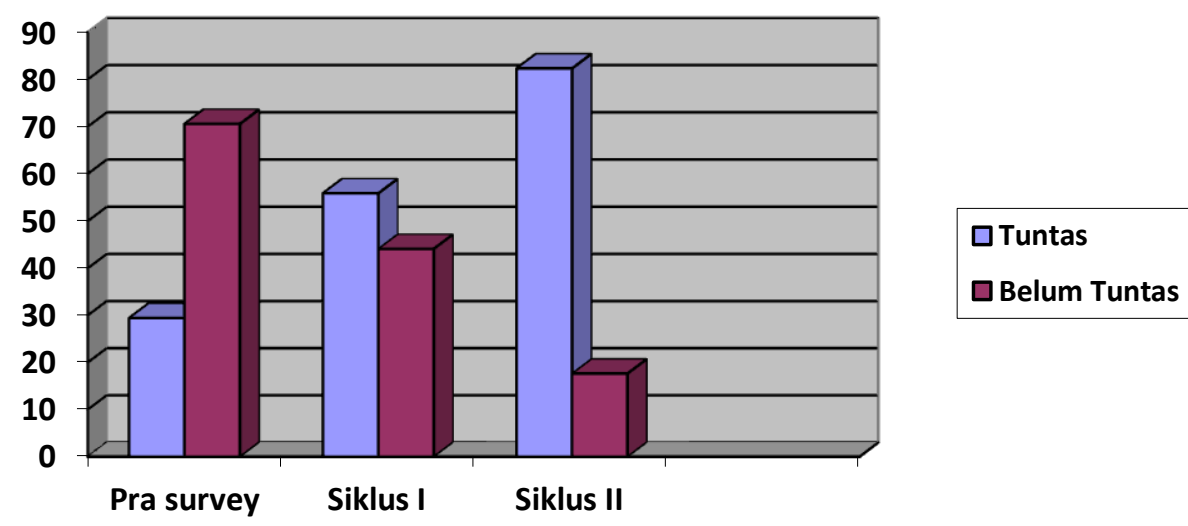

Berdasarkan analisis pada pembahasan sebelumnya maka dapat disimpulkan bahwa sebelum menerapkan Metode PQRST yang tuntas terdapat 10 orang Peserta didik $(29,41 \%)$ dan yang belum tuntas 24 orang Peserta didik (70,59\%). Selanjutnya, pada siklus I hasil belajar Peserta didik pada materi Makanan dan minuman yang halal dengan menerapkan Metode PQRST mengalami peningkatan yaitu terdapat 19 orang Peserta didik yang tuntas $(55,88 \%)$ dan yang belum tuntas 15 orang Peserta didik $(44,22 \%)$. Lalu pada siklus II pada materi Makanan dan minuman yang haram diketahui Peserta didik yang tuntas ada 28 orang Peserta didik $(82,35 \%)$ dan yang belum tuntas ada 6 orang Peserta didik (17,65\%). Jadi peningkatan dari siklus I ke siklus II yaitu 26,47\%. Maka dapat disimpulkan bahwa penerapan Metode PQRST pada materi Makanan dan minuman yang halal dan haram hasil belajar Peserta didik mengalami peningkatan yang signifikan atau dapat dikatakan bahwa mereka mampu mencapai Mastery Learning yang telah ditentukan yaitu 75-80\%.

\section{SIMPULAN DAN SARAN}

Berdasarkan hasilpenelitiandan analisis data, maka dapat disimpulkan bahwa, melaluipenerapanmetode PQRST (Preview, Question, Read, Summarize and Test) dapatmeningkatkanhasilbelajar matapelajaranfiqhPesertadidikkelas V di MI tersebut tahun pelajaran 2016/2017. 


\section{DAFTAR PUSTAKA}

Ardana, K., Suandi, N., \& Artawan, G. (2014). Pengaruh Penerapan Metode Membaca PQRST Ditinjau dari Minat Membaca terhadap Kemampuan Pemahaman Isi Bacaan Berbasis Teks Cerita pada Siswa Kelas IX SMP Negeri 2 Dawan. Jurnal Pendidikan Dan Pembelajaran Bahasa Indonesia, 3(1).

Arikunto, S. (2008). Penelitian Tindakan Kelas. Jakarta: Bumi Aksara.

Depdikbud. (1996). Dedaktif Metodik Umum. Jakarta: Direktorat Pendidikan Dasar.

Hidayah, N., Suwandi, S., \& Hastuti, S. (2014). Penerapan Metode PQRST Untuk Meningkatkan Minat Dan Kemampuan Membaca Pemahaman Siswa. BASASTRA, 2(3), 1-13.

Jayanthi, N. W. L., Garminah, N. N., \& Md. Suarjana. (2013). Pengaruh Metode PQRST Terhadap Pemahaman Konsep IPA Siswa Kelas V SD Di Gugus 5 Kecamatan Kediri. Mimbar PGSD, 1(1).

Mariana, Miharty, \& Thaib, A. (2015). The Use Of Motode Preview Question Read State And Test (PQRST) Can Improve Student Achievement On The Subject Of Atomic Structure Class X IPA SMA Muhammadiyah 1 Pekanbaru. Jurnal Online Mahasiswa (JOM) Bidang Keguruan Dan Ilmu Pendidikan, 2(2), 1-10.

Milasari, H., Mahfud, H., Sadiman, \& Sriyanto, M. I. (2015). Peningkatan Kemampuan Membaca Pemahaman Cerita Anak Melalui Metode Preview, Question, Read, Summarize, Test (PQRST). Jurnal Didaktika Dwija Indria, 3(7), 1-5.

Mulyasa, E. (2004). Kurikulum Berbasis Kompetensi : Konsep, Karakteristik dan Penerapan. Bandung: Remaja Rosda Karya.

Nur Canggih Tri Wiguna. (2015). Peningkatan Kemampuan Membaca Pemahaman Teks Bacaan Narasi Dengan Menggunakan Metode PQRST Pada Siswa SMP Negeri 2 Susukan Kabupaten Banjarnegara Tahun Pelajaran 2013/2014. Jurnal Surya Bahtera, 3(21), 1-8.

Nurhadi. (1987). Membaca Cepat dan Efektif. Malang: Sinar Baru.

Nurkencana, W. (1993). Evaluasi Pendidikan. Surabaya: Usaha Nasional.

Purwati. (2016). Peningkatan Kompetensi Dan Hasil Belajar Bahasa Indonesia Materi Teks Percakapan Melalui Metode PQRST Siswa Kelas VI SDN Ngastorejo. Jurnal Pendas, 3(1), 43-52.

Riduwan. (2007). Belajar Mudah Penenlitian Untuk Guru, Karyawan Dan Peneliti Pemula. Bandung: Alfabeta.

Sada, H. J. (2016). Manusia Dalam Perspsektif Agama Islam. Al-Tadzkiyyah: Jurnal 
Pendidikan Islam, 7(1), 129-142.

Selameto. (1995). Belajar dan Faktor-faktor Yang Mempengaruhinya. Jakarta: Rineka Cipta.

Sudjana, N. (2004). Penilaian Hasil Proses Belajar Mengajar (9th ed.). Bandung: Remaja Rosda Karya.

Sudjiono, A. (2008). Pengantar Statistik Pendidikan. Jakarta: Raja Grafindo.

Sugiyono. (2011). Metode Penelitian Kuantitatif dan R \& D. Bandung: Alfabeta.

Sukaesih, S. (2014). Peningkatan Kemampuan Membaca Pemahaman Wacana Nonsastra Berbahasa Jawa Dengan Metode PQRST. Pendidikan Bahasa Dan Sastra Jawa, 4(2), 61-67.

Wahid, A., \& Amarwanti, D. (2015). Keefektifan Metode PQRST (Preview, Question, Read, Summerize, Test) Dalam Membaca Pemahaman Teks Bacaan Pada Mata Pelajaran Bahasa Indonesia Siswa Kelas VII SMP NEGERI 1 Bontomatene Kabupaten Kepulauan Selayar. Jurnal Pendidikan Konfiks, 2(2), 103-108.

Wahyuni, N. N. S., Putra, D. K. N. S., \& Abadi, I. B. G. S. (2014). Pengaruh Metode Pembelajaran PQRST Berbantuan Media Semi Konkrit Terhadap Keterampilan Membaca Bahasa Indonesia Kelas IV SDN Gugus I Denpasar Selatan. Jurnal Mimbar PGSD Universitas Pendidikan Ganesha, 2(1). 